\title{
Cytogenetics of coffee
}

\author{
Cecília A. F. Pinto-Maglio
}

Laboratório de Citogenética, Centro de Pesquisa e Desenvolvimento de Recursos Genéticos Vegetais, Instituto Agronômico de Campinas, CP 28, 13001-970, Campinas, SP, Brasil. E-mail: maglio@iac.sp.gov.br

The genus Coffea L. has around 100 native species distributed in tropical and subtropical areas in Africa, and the most important economic species are C. arabica and C. canephora. C. arabica is exceptional in the genus since it is the only species so far analyzed which is self-compatible, and a natural polyploid with $2 n=4 x=44$ chromosomes; it is considered to be a segmental allopolyploid because it presents a disomic inheritance and a regular meiotic behavior. All other species in the genus are selfincompatible diploids with $2 \mathrm{n}=2 \mathrm{x}=22$. Cytogenetic studies in Coffea, undertaken since 1912, have followed various phases: initial studies were limited only to establishing chromosome counts. Subsequent studies characterized the karyotypes of various species using conventional cytological techniques. As the somatic metaphase chromosomes of coffee are very small $(1-3 \mu \mathrm{m})$ and morphologically symmetrical, these studies resulted in uniform karyotypes that show almost no differences among species. Since genetic improvement of coffee trees has progressed mainly by means of interspecific hybridizations involving wild species, analyses of microsporogenesis in species and hybrids were needed to establish their genetic affinity and relationships. The first successful attempts to differentiate coffee chromosomes longitudinally were made by mapping pachytene chromomeric patterns and by $\mathrm{C}$ and NOR banding techniques. From 1998 onwards, the use of banding techniques with the fluorochromes DAPI and $\mathrm{CMA}_{3}$, and also the cytomolecular technique FISH using rDNA probes, has increased the longitudinal differentiation of coffee chromosomes. The use of the GISH technique with total genomic DNA has revealed the parental species that originated C. arabica species.

Key words: Coffea, chromosomal characterization, karyotype, meiotic behavior, chromomere pattern, chromosome banding, molecular cytogenetics.

Citogenética de café (Coffea L.): O gênero Coffea L., com cerca de 100 espécies nativas de regiões tropicais e subtropicais da África, tem as espécies Coffea arabica e C. canephora como comercialmente importantes. C. arabica é uma exceção no gênero por ser o único poliplóide natural com $2 n=4 x=44$ cromossomos e autocompatível sendo considerado um alopoliplóide segmental devido à herança dissômica e comportamento meiótico regular. As demais espécies são diplóides autoincompatíveis com $2 \mathrm{n}=2 \mathrm{x}=22$. Estudos citogenéticos em Coffea têm sido realizados, desde 1912, com diferentes finalidades. Os primeiros visaram apenas a contagem de cromossomos. Em seguida, estudos morfológicos em cromossomos somáticos com técnicas citológicas convencionais objetivaram a caracterização das diferentes espécies. Devido o fato dos cromossomos de café serem relativamente pequenos $(1-3 \mu \mathrm{m})$, e morfologicamente simétricos, estes estudos revelaram cariótipos homogêneos entre as diferentes espécies. O melhoramento genético do cafeeiro, realizado através de hibridações interespecífcas envolvendo espécies selvagens diplóides, demandou estudos da microsporogênese, em espécies e híbridos, com vistas ao estabelecimento de relações de afinidade genética entre as mesmas. O mapeamento do padrão cromomérico, na fase de paquíteno, juntamente com o surgimento do bandeamento $\mathrm{C}$ e NOR, conduziu às primeiras tentativas de se diferenciar longitudinalmente os cromossomos

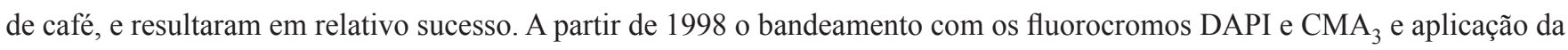
técnica de FISH, com sondas de rDNA, vêm incrementando a diferenciação dos cromossomos e a aplicação da técnica GISH, com sondas de DNA genômico total, confirmaram as espécies parentais de C. arabica.

Palavras-chave: Coffea, caracterização cromossômica, cariótipo, comportamento meiótico, padrão cromomérico, bandeamento cromossômico, citogenética molecular. 


\section{INTRODUCTION}

The number of species in the genus Coffea L. (family Rubiaceae, subfamily Cinchonoideae, tribe Coffeeae) is still uncertain, but most taxonomic works indicate that this genus comprises about 100 species (for a review see Charrier and Berthaud, 1985; Wringley, 1988). Although morphologically quite distinct, Coffea species present some common genetical features, such as the small variation in the chiasmata number (Mendes, A.J.T., 1950; Mendes C.H.T., 1950; Medina, 1950, 1952; Conagin, 1961; Medina and Rijo, 1969; Medina et al., 1977) and the high frequency of bivalents in interspecific hybrids (Medina, 1972). Several studies have been carried out to establish precisely the relationships between species in the genus Coffea (Carvalho and Mônaco, 1967; Chinnappa, 1981; Lashermes et al., 1996, 1997), but interspecific relationships in this genus are still controversial since the affinities among species based on morphological characteristics and/or geographical distributions conflict with the relationships indicated by hybridizations and the cytological analyses of such hybrids (Carvalho and Mônaco, 1967; Medina 1972).

Another focus in coffee cytogenetical research has been the origin of the species Coffea arabica L. This is the only polyploid $(2 n=4 x=44)$ and self-compatible species in the genus, and all other species are diploid $(2 n=2 x=22)$ and self-incompatible. Based on different kinds of analyses (Krug and Carvalho, 1951; Grassias and Kammacher, 1975; Pinto-Maglio and Cruz, 1998, Lashermes et al. 1999), C. arabica has been considered to be a segmental allopolyploid, and various diploid species have been suggested as possible ancestrals. The main problem that has complicated the development of cytogenetic research in the genus Coffea has been the small size of the chromosomes, and the uniform karyotypes of the species.

Cytogenetic research in coffee has embraced the following phases: (1) An exploratory phase which accompanied taxonomical studies on the Rubiaceae family, in which chromosome counts were made for various species and the basic number for the genus was determined; (2) A second phase, in which some attempts were made to characterize morphologically the somatic chromosomes, and construct karyotypes, with the aim to employ these data in comparative studies; (3) Subsequently, several studies were made on the meiotic behavior of species and hybrids, and attempts were made to use pairing indices of bivalents to determine phylogenetic relationships among different species, with the objective of applying these data to interspecific hybridizations. Some of these studies facilitated some important crossbreeding of coffee plants; (4) In this phase, which began some 15 years ago, different techniques have been employed with various species of coffee to characterize longitudinal chromosome differentiation, and so overcome the problems posed by the small size of the chromosomes and the similarity of the chromosome complements. These have included studying pachytene chromomeric patterns, $\mathrm{C}$ and NOR banding, and banding revealed by the fluorochomes 4'-6-diamidino-2phenylindole (DAPI) and Chromomycin $\left(\mathrm{CMA}_{3}\right)$, and more recently, cytomolecular techniques such as fluorescence in situ hybridization (FISH), and genomic in situ hybridization (GISH). These phases are discussed in more detail below.

\section{Number and morphology of coffee chromosomes}

The basic chromosome number for the genus Coffea is considered to be $\mathrm{n}=11$, which is typical for most genera of the family Rubiaceae. Virtually all Coffea species are diploid $(2 n=2 x=22)$ and self-incompatible, and Coffea arabica $\mathrm{L}$. is the only polyploid species $(2 n=4 x=44)$ of the genus, and it is self-compatible. Early reports of chromosome counts for Coffea arabica and other species of the genus were rather unfocused since they were published in general studies on the Rubiaceae. The earliest citation was made by Faber (1912), with a somatic chromosome count of $2 \mathrm{n}=16$ for $C$. arabica. Subsequent chromosome counts for this species were also made by researchers who were interested not only in coffee but also other genera of the Rubiaceae, e.g. Homeyer (1933 in Krug, 1934), who reported $2 \mathrm{n}=44$ chromosomes for $C$. arabica, and established $\mathrm{n}=11$ as a basic number for the genus Coffea. Likewise, Fagerlind (1937), investigating cytology of Rubiaceae, confirmed Homeyer's count of $2 n=44$ for C. arabica, and determined the chromosome number for many other species of Coffea. As has been reviewed by Sybenga (1960), during 1930s a series of studies of chromosome counts were made for most species of the genus Coffea and also for some representatives of Psilanthus, a genus taxonomically very closely related to Coffea.

The most important studies on the cytogenetics of Coffea have been carried out at the Instituto Agronômico in Campinas, Brazil, and by French researchers in the Ivory Coast and Equatorial Africa, and by Belgian researchers in the previous Belgian Congo (Frahm-Leliveld et al., 1969; Wringley, 1988). In Brazil, Krug (1934) made the first of a series of studies on coffee cytology that resulted in chromosome number determinations for eight different species of Coffea and 17 varieties of C. arabica (among 
others, amarelo de Botucatu, nacional, bourbon, laurina, maragogipe, a haploid variety monosperma, and hexaploid and octoploid forms of the variety bullata). These studies indicated a uniform number of chromosomes $(2 n=44)$ for all varieties of $C$. arabica, and it was demonstrated for the first time that, despite the tetraploid condition, this species shows normal meiotic behavior. Subsequently, many other species, varieties, cultivars, and interspecific hybrids, with different levels of ploidy, such as triploids, tetraploids, hexaploids and octoploids, also had their chromosome number established (Krug, 1937, Mendes, 1938; Medina, 1950, 1952, 1972).

From 1938 onwards, in addition to chromosome number determinations, some researchers tried to establish the morphology of coffee somatic chromosomes. Although Krug $(1934 ; 1937)$ had reported some observations on chromosome size and morphology for some coffee species, Mendes (1938) was the first to attempt to describe the morphology of somatic chromosomes for the genus Coffea, with the species $C$. excelsa Chev. (currently C. dewevrei Wild. et Dur.). Mendes (1938) noted that although the chromosomes of this species were larger than those of other Coffea species, they were still relatively very small $(1.5$ a $3.5 \mu \mathrm{m})$ and morphologically similar to each other. He could only distinguish three classes (A, B and C) according to total length, and only the first three chromosomes of the class A were differentiated based in their morphology. This study was the first to demonstrate the pronounced morphological similarity among coffee chromosomes. More extensive studies to characterize the coffee somatic chromosome morphology were made by Bouharmont (1959; 1963). He observed a great similarity among the karyotypes of 16 species including the tetraploid C. arabica, and was unable to distinguish between the karyotypes of the analyzed species. He published an average ideogram for the 11 chromosomes of the basic genome for the genus Coffea in which it was possible to distinguish between only four of them. Effectively, all these authors demonstrated that the species of the genus Coffea have chromosomes which are scarcely differentiated morphologically and which are probably the same as the ancestral genome.

Studies on meiotic pairing have demonstrated that this morphological similarity is present even among the chromosomes of the allotetraploid complement of $C$. arabica, more specifically among the parental genomes that constitute the hybrid complement of this species. Data about meiotic behavior, or the index of bivalent pairing in haploids, are important because in plants of allopolyploid origin, like Coffea arabica, the double presence of only one genome may reveal the homeologies that are present among the genomes that form the allopolyploid. In this condition, the preferential homologue pairing normally present in euploid condition is absent, and the homeologue pairing can be totally expressed. In a di-haploid of C. arabica, Mendes and Bacchi (1940) found $71 \%$ of the cells with 1 to 6 bivalents. Based on this kind of analysis, Vishveshwara (1960) also registered the presence of bivalents in $40 \%$ of the analyzed cells of some haploid plants of cultivated varieties of C. arabica. Using dihaploids of natural plants of this species, collected directly from the area of origin in Ethiopia, Berthaud (1976) counted 63 cells with 22 chromosomes with 2 to 8 bivalents, with the cells with 4 bivalents being the most frequently observed. Another experiment with di-haploids was also made by Kammacher (1980). This author analyzed the meiotic behavior of five di-haploids plants of C. arabica, focusing not only on the bivalent pairing capacity but also on the formation of chiasmata at metaphase I. He found a median frequency of 2.29 bivalents and 3.19 chiasmata per cell. Kammacher concluded that the genomes of $C$. arabica have a residual affinity between three chromosomes, and this explains the presence of up to six bivalents in meiosis. He concluded that the chromosomes had remained homosequentials since the formation of the ancestral allopolyploid species of arabica, i.e. they have not changed. Another paper, published by Grassias and Kammacher (1975), on meiotic behavior in three different varieties of $C$. arabica: tana, guinnée, pita and caturra amarelo, described some irregularities such as asynaptic chromosomes, secondary associations between bivalents and the presence of some multivalents. These irregularities had never been seen before, and led these authors to conclude that $C$. arabica was a segmental allotetraploid taxon, i.e. it was formed by two genomes with chromosomes that conserve great similarity.

\section{Cytogenetics and breeding}

The increasing commercial importance of coffee at the beginning of the 1950s, led to intensive research involving improvement breeding programs. As a consequence, from 1950 until 1978, all the information available for the cytogenetics of Coffea was mainly derived from studies involving plant breeding in $C$. arabica. Such breeding studies with coffee were mainly been carried out by means of intraspecific and interspecific hybridizations involving the two cultivated species Coffea arabica and C. canephora, as well as many wild coffee species. These hybridizations demanded the development of cytogenetic studies mainly on 
microsporogenesis or meiotic behavior of chromosomes so as to establish the degree of genetic affinity between the species. A description of meiotic behavior in varieties of $C$. arabica such as semperflorens and caturra was published by Mendes (1950). He analyzed the number of nucleolar chromosomes, number of chiasmata per cell, pairing of bivalents and the pollen formation, and concluded that microsporogenesis in these varieties was normal. Medina (1950) also analyzed the microsporogenesis of $C$. arabica $\mathrm{L}$. var. rugosa to explain the low productivity of this variety and the lack of the wrinkled (rugosa) characteristic in the progenies of these plants. In addition to these varieties of $C$. arabica, similar analyses on microsporogenesis were made for several diploid species of Coffea, mainly those used in interspecific hybridizations with C. arabica (Mendes, 1950; Medina, 1952; Conagin, 1961; Medina and Rijo, 1969; Medina et al., 1977; Boaventura and Cruz, 1987). However, despite these studies on meiotic behavior, the characterization of individual chromosomes remained an important desideratum for progress with cytological research on coffee. Initially, the importance of this aspect was demonstrated by the studies with aneuploids of C. arabica cultivar "Mundo Novo" made by Cruz (1972) in which she found it impossible to associate the plant morphology with the lack or excess of chromosomes in nullisomics and monosomics. This sort of problem has constrained the use of aneuploids in plant breeding programs since it was impossible to associate genes to chromosomes, for example, in the construction of addition or substitution lines for gene transferences.

\section{Longitudinal chromosome differentiation}

After several years of cytological research with many species, varieties and cultivars of Coffea, Medina et al. (1977) concluded that the use of conventional staining techniques to attempt to study the number of chiasmata in individual species, or the meiotic behavior in interspecific hybrids, or the construction of karyotypes from somatic chromosomes, would be unable to shed light on the phylogenetic relationships of Coffea species. As a consequence, adequate methods to determine chromosomal identities remained a priority for the coffee cytogenetics. At that time Medina et al. (1977) suggested that comparative analyses of meiotic chromosomes at the pachytene phase, or C banded somatic chromosomes, might provide good chromosomal characterization. Taking up this suggestion, Pinto-Maglio and Cruz (1987) undertook an experimental identification of nucleolar chromosomes so as to verify the possibility of using chromosome appearance at meiotic pachytene phase to identify coffee chromosomes. These authors characterized the chromomeric pattern of nucleolar chromosomes from 10 species of Coffea, including the tetraploid $C$. arabica, and they concluded that since the chromomeric pattern in each species was specific and constant, this technique could be used to distinguish coffee chromosomes. These authors (Pinto-Maglio and Cruz 1998) subsequently characterized all 22 bivalents of tetraploid $C$. arabica. The pachytene chromomeric pattern in this species revealed that there were some structural similarities in about $54 \%$ of the bivalents, i.e. twelve pairs of bivalents have very similar morphology. Two secondary associations were also observed. These observations reconfirmed the marked homeology among the chromosomes of the arabica complement and also confirmed the segmental allopolyploid condition of this species. This high chromosomal similarity, contrasting with the low level of pairing abnormality, e.g. multivalent formation, indicates that maybe there exists in C. arabica a genetically controlled system that prevents homeologous chromosome pairing. Banding techniques, particularly $\mathrm{C}$ banding and NOR banding, or silver impregnation (AgNOR), opened up new perspectives to characterize coffee chromosomes, since conventional squash preparations with acetic orcein or the use of Feulgen had proved relatively unsuccessful (Pierozzi, 1993). The C banding technique allows the localization of the heterochromatin segments of DNA present on the homologous chromosomes, that are differentiated from the euchromatin segments that present the normal chromosome coiling. The NOR banding technique differentiates chromosomes by localization of the active nucleolar organization regions. Almost in parallel with the pachytene analyses, Pierozzi (1993) made comparative studies on Coffea utilizing $\mathrm{C}$ banding to establish karyotypes for some diploid species such as C. canephora, C. liberica var. dewevrei and C. racemosa, and also used NOR banding or silver impregnation (Ag-NOR) with the same species, so as to localize the active nucleolar organization regions and so attempt to characterize the somatic chromosomes at mitosis. In this pioneer attempt, Pierozzi (1993) described the difficulties she encountered in adapting these banding techniques for coffee chromosomes, and she managed to only partially characterize the karyotypes of these species. Subsequent modifications to the $\mathrm{C}$ band methodology which were particularly appropriate for plants with small chromosomes like coffee, produced better $\mathrm{C}$ banding patterns for some wild species, and the description of the complete karyotypes for the species $C$. canephora and $C$. dewevrei. All the species 


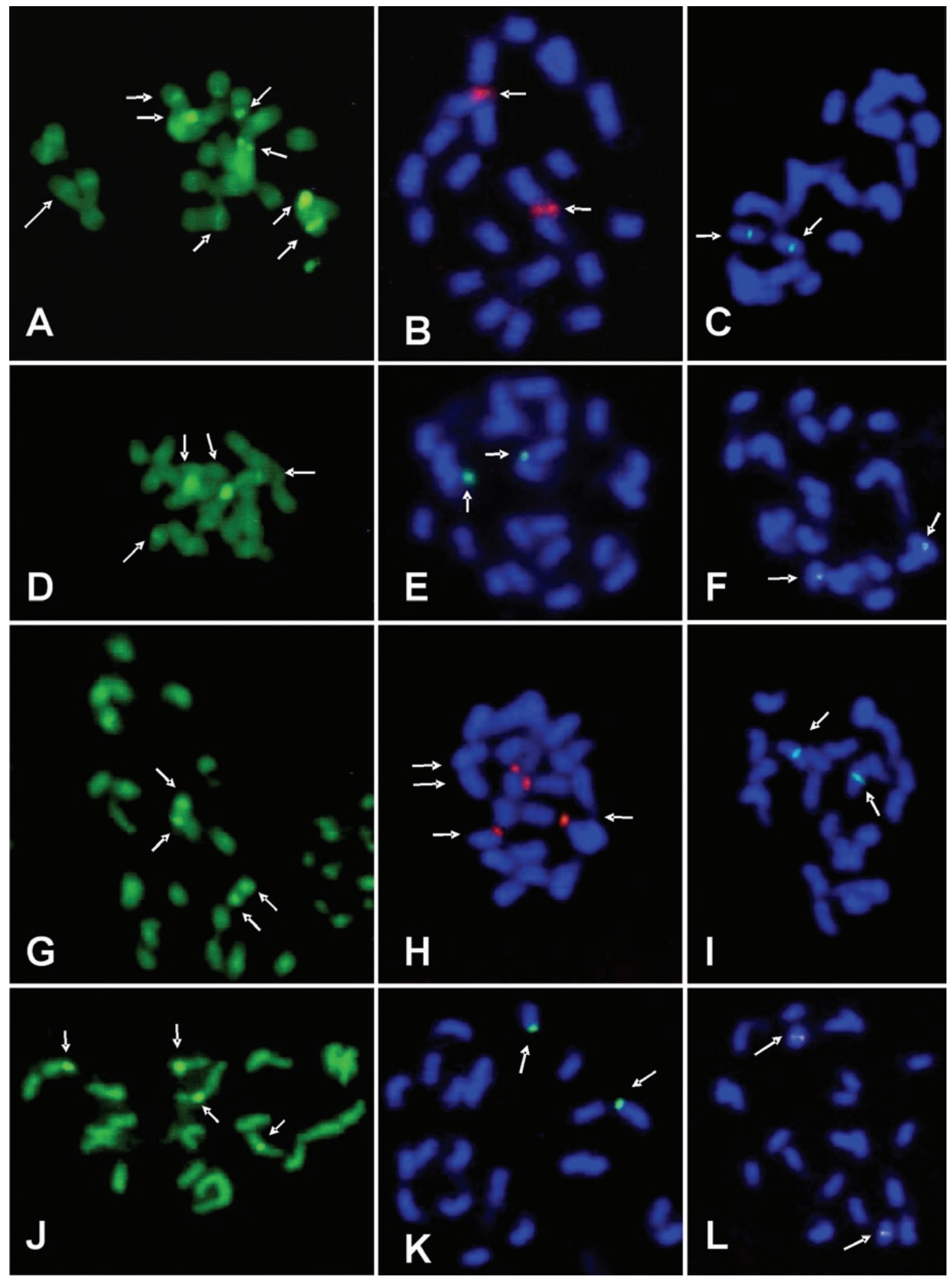

Figure 1. Cells in mitotic metaphase with arrows showing signals of $\mathrm{CMA}_{3}$ positive bands (A, D, G and J); pTa71 with signals in red when biotin-labelled (B and $\mathrm{H}$ ) and in green when digoxigenin-labelled (E and $\mathrm{K})$, and pScT7 with signals in green (C, F, I and L) in wild Coffea species: C. humilis (A, B and C), C. kapakata (D, E and F), C. sp. Moloundou (G, H and I) and C. stenophylla (J, K and L). (From Lombello and Pinto-Maglio, 2004a) 
studied presented the chromosomes with uniform pericentromeric patterns of $\mathrm{C}$ banding, suggesting that during evolution, the wild species have retained not only the same chromosome number but also the same pattern of distribution of heterochromatin as revealed by the $\mathrm{C}$ bands (Pierozzi et al., 1999; 2001).

The characterization of the longitudinal differentiation of the mitotic chromosomes of coffee has progressed using other techniques such as fluorescent banding with DAPI (4'6-diamidino-2-phenylindole) and $\mathrm{CMA}_{3}$ (Chromomycin $\mathrm{A}_{3}$ ) that identify chromatin regions rich in $\mathrm{A}-\mathrm{T}$ and $\mathrm{G}-\mathrm{C}$ bases, respectively; in addition, cytomolecular techniques such as fluorescent in situ hybridization (FISH) and genomic in situ hybridization (GISH) have also been applied (Pinto-Maglio et al., 2000; 2001; Barbosa et al., 2001; Lombello and PintoMaglio, 2004a,b,c).

The FISH technique detects in situ specific DNA sequences on chromosomes, and GISH detects partial or whole genomes in hybrids. These techniques are very appropriate for small and morphologically similar chromosomes because the identification is totally independent from size or shape of the chromosomes but is based in the presence or absence of specific DNA sequences (probes) and their number and localization in the complement. Since 1998 at the Instituto Agronômico at Campinas, Brazil, a project that aims to characterize cytologically the species of Coffee Germoplasm Bank has being developed through chromosome banding with fluorochrome staining and also by chromosome mapping through FISH assays. To date, 14 species of the genus Coffea and three species of the closely related genus Psilanthus have been characterized using banding assays with the fluorochromes DAPI and CMA, and also with FISH. For the FISH assays, two different specific probes of ribosomal DNA (rDNA) were used: pTa71, a highly conserved sequence that corresponds to a $9 \mathrm{~Kb}$ rDNA sequence of 18S-5.8S-26S isolated from Triticum aestivum; and pScT7 probe, a sequence that corresponds to a 300-500 bp rDNA from Secale cereale. The results of the analyses of these fourteen species (Pinto-Maglio et al., 2000; 2001; Barbosa et al., 2001; Lombello and Pinto-Maglio, 2004a,b,c) revealed differences in presence, number and position of DAPI/CMA bands and the rDNA sites among them. Part of these data is shown in figure 1. The FISH technique has proved to be excellent for differentiating coffee chromosomes and a very important alternative for the cytogenetic characterization of the species of Coffea, and also for future gene or DNA specific sequence mapping.
Some other studies using FISH and GISH were dedicated mainly to solve the origin and genetic constitution of C. arabica. The total genomic DNA was used as probe to GISH, and ribosomal DNA sequences as probe to FISH, both to study the genomic organization and C. arabica evolution, and to discover the ancestral species of this species among: C. eugenioides, C. congensis, C. canephora and C. liberica. The results showed the presence the two distinct genomes of $C$. eugenioides and C. congensis in the complement of $C$. arabica, confirming its allopolyploid condition (Raina et al., 1998). A second study (Lashermes et al., 1999), also using GISH and RFLP markers, determined the amphidiploid origin of $C$. arabica, and in contrast to the previous study, the results showed that arabica probably derives from natural hybridization between the diploids $C$. eugenioides and $C$. canephora.

\section{Concluding remarks}

The characterization of individual chromosomes in species of Coffea is still a matter of great interest, since it would permit chromosome mapping of many potentially useful genes. A cytogenetic map would provide complementary information for the genetic linkage maps and molecular markers maps, which are currently being developed, permitting the location of genes and/or specific DNA sequences in relation to features of chromosomal organization. The integration of cytogenetic and genetic maps has been achieved in some species of diverse genera by utilizing mainly chromosome anomalies, such as translocation breakpoints, deletions or trisomics. However, these techniques would be impractical for species like coffee due to the absence of distinct cytological features, and as a consequence, FISH has proved to be an alternative approach for the characterization of individual chromosomes and chromosome mapping.

Acknowledgements: We are grateful to Dr. Peter Gibbs (University of St Andrews, Scotland) for a revision of the English text.

\section{REFERENCES}

Barbosa RL, Pierozzi NI, Lombello RA, Silvarolla MB, Pinto-Maglio CAF (2001) Caracterização citomolecular de três espécies de Coffea L.: C. eugenioides, C. canephora, e $C$. dewevrei In: II Simpósio De Pesquisa Dos Cafés Do Brasil. Vitória, Brasil, 293-298

Berthaud J (1976) Étude cytogenétique d'un haploide de $C$. arabica L. Café Cacao Thé, 20:91-96. 
Boaventura YMS, Cruz ND da (1987) Citogenética do híbrido interespecífico (Coffea arabica L. var. Bourbon X C. canephora Pierre ex Froehner var. Robusta (Linden) Chev) que originou o café Icatu. Turrialba 37:171-178.

Bouharmont J (1959) Recherches sur les affinités chromosomiques dans le genre Coffea. INEAC,94pp. (Série scientifique $\left.n^{\circ} 77\right)$ Bruxelles.

Bouharmont J (1963) Somatic chromosomes of Coffea species. Euphytica 12:254-257.

Carvalho A, Mônaco LC Genetic relationship of selected species of coffee. (1967) Ciên. Cult. 19:151-165.

Charrier A, Berthaud J (1985) Botanical classification of coffee. In: Clifford MN, Wilson KC (eds), Coffee: Botany, Biochemistry and Production of Beans and Beverage, pp.13-47. AVI Publishing Company, Inc., Westport, Connecticut, USA.

Chinnappa CC (1981) Palynology and systematics of the genus Coffea. J. Coffee Res.11:55-69.

Conagin CHTM (1961) Microsporogênese, incompatibilidade e esterilidade masculina em Coffea congensis Froehner. Bragantia 20:669-677.

Cruz ND (1972) Aneuplóides de café - Aspectos morfológicos e citológicos na análise de duas progênies do café "Mundo Novo" (Coffea arabica). Piracicaba, Escola Superior de Agricultura "Luiz de Queiroz" da USP, Doctorate thesis.

Faber FC (1912) Morphologish-Physiologische untersunchungen an Blüten von Coffea-arten. Ann. Jard. Bot. Buitenz. 25:59-160.

Fagerlind F (1937) Embryologische, Zytologische und Bestäubugsexperimentelle Studien in der Familie Rubiaceae nebst Bermerkungen über Einige Polyphoiditatsprobleme. Acta Horti-Bergiani 11:199-460.

Frahm-Leliveld JA Medina, DM, Mendes AJT (1969) Cytology, gametogenesis and development of seed and fruit. In: Ferwerda FP, Wit F (eds), Outlines of Perennial Crop Breeding in the Tropics, pp. 192-198. H. Veenman \& Zonen NV, Wageningen, The Netherlands.

Grassias M, Kammacher P (1975) Observation sur la conjugaison chromosomique de Coffea arabica L. Café Cacao Thé 19:177-190.

Kammacher P (1980) Sur le comportment méiotique des dihaploides de Coffea arabica L. In: $9^{\text {eme }}$ Colloque Scientifique International sur le café (Londres), ASIC, Paris, pp.717-723.

Krug CA (1934) Contribuição para o estudo da citologia do gênero Coffea. Campinas, Instituto Agronômico, Boletim Técnico 11. pp.1-10.

Krug CA (1937) Observações citológicas em Coffea. III. Campinas, Instituto Agronômico. Boletim Técnico 37. pp.1-19.

Krug CA, Carvalho A (1951) The genetics of Coffea. Adv. Genet. 4:127-158.

Lashermes P, Cros J, Combes MC, Trouslot P, Anthony F, Hamon S, Charrier A (1996) Inheritance and restriction fragment length polymorphism of chloroplast DNA in the genus Coffea L. Theor. Appl. Genet. 93:626-632.

Lashermes P, Combes MC, Trouslot P, Charrier A (1997) Phylogenetic relationships of coffee-tree species (Coffea L.) as inferred from ITS sequences of nuclear ribosomal DNA. Theor. Appl. Genet. 94:947-955.

Lashermes P, Combes MC, Robert J, Trouslot P, D'Hont P, Anthony F, Charrier A (1999) Molecular Characterization and origin of the Coffea arabica L. genome. Molecular and General Genetics 261:259-266.

Lombello RA, Pinto-Maglio CAF (2004a) Heterochromatin and rDNA sites in Coffea L. chromosomes revealed by FISH and CMA/DAPI. I. C. humilis, C. kapakata, C. sp. Moloundou and C. stenophylla. Caryologia 57:11-17.

Lombello RA, Pinto-Maglio CAF (2004b) Heterochromatin and rDNA sites in Coffea L. chromosomes revealed by FISH and CMA/DAPI. II. C. canephora cv. Apoatã, C. salvatrix, C. sessiliflora. Caryologia 57:138-143.

Lombello RA, Pinto-Maglio CAF (2004c) Cytogenetic studies in Coffea L. and Psilanthus Hook. f. using CMA/DAPI and FISH. Cytologia 69:85-91.

Medina DM (1950) Observações citológicas em Coffea. XIV - Microsporogênese em $C$. arabica L. var. rugosa KMC. Bragantia 10: 61-66

Medina DM (1952) Observações citológicas em Coffea. XIX - Microsporogênese em C. dewevrei. Bragantia 12:153162.

Medina DM (1972) Caracterização de híbridos interespecíficos de Coffea. Piracicaba, Escola Superior de Agricultura "Luiz de Queiroz" da USP, Doctorate thesis.

Medina DM, Rijo L (1969) Microsporogênese em C. stenophylla G. Don. E C. salvatrix Swynn et Phil. Bragantia 28:307-322.

Medina DM, Conagin CHTM, Cruz ND (1977) Microspororogenesis in diploid species of Coffea. Caryologia 30: $13-25$.

Mendes AJT (1938) Morfologia dos cromossomos de Coffea excelsa Chev. Campinas, Instituto Agronômico. Boletim Técnico 56: pp1-8.

Mendes AJT (1950) Observações citológicas em Coffea. XVMicrosporogênese em C. arabica L. Bragantia 10:79-87.

Mendes AJT, Bacchi O (1940) Observações citológicas em Coffea. V. Uma variedade haplóide (di-haplóide) de C. arabica L. J. Agron. 3:183-206.

Mendes CHT (1950) Observações citológicas em Coffea. XV I- Microsporogênese em C. canephora Pierre ex Froehner. Bragantia 10:97-104.

Pierozzi NI (1993) Identificação, por métodos de bandamento, dos cromossomos de Coffea (Coffea canephora Pierre ex Froehner; $C$. dewevrei De Wild et Th. Dur.; C. racemo$s a$ Lour.). Campinas, UNICAMP. Doctorate thesis.

Pierozzi NI, Pinto-Maglio CAF, Cruz ND (1999) Characterization of somatic chromosomes of two diploid species of Coffea L. with acetic orcein and C-band techniques. Caryologia 52:1-8.

Pierozzi NI, Pinto-Maglio CAF, Silvarola B, Barbosa RL (2001) Karyotype characterization in some diploid coffee species by acetic orcein, C-band and $\mathrm{AgNO}_{3}$ techniques. In: $14^{\text {th }}$. International Chromosome Conference, Würzburg, Germany. 2001. Chromosome Res. 9(1):99. 
Pinto-Maglio CAF, Cruz ND (1987) Pachytene chromosome morphology in Coffea L. I. Nucleolar chromosomes. Caryologia 40:7-23.

Pinto-Maglio CAF, Cruz ND (1998) Pachytene chromosome morphology in Coffea L. II. C. arabica L. complement. Caryologia 51:19-35.

Pinto-Maglio CAF, Cuéllar T, Barbosa RL (2000) Aplicação de técnicas de citogenética molecular na caracterização dos cromossomos da espécie Coffea arabica L. In: Anais do I Simpósio da Pesquisa dos Cafés do Brasil, Poços de Caldas, Brasil, pp.444 - 446.

Pinto-Maglio CAF, Barbosa RL, Cuéllar T, Maluf MP, Pierozzi NI, Silvarolla MB, Orsi CH (2001) Chromosome characteri- zation in Coffea arabica L. using cytomolecular techniques. In: $14^{\text {th }}$ International Chromosome Conference, Würzburg, Alemanha, Chromosome Research pp.100.

Raina SN, Mukai Y, Yamamoto M. (1998) In situ hybridization identifies the diploid progenitor species of Coffea arabica (Rubiaceae). Theor. Appl. Genet. 97:1204-1209.

Sybenga J (1960) Genetics and cytology of Coffea. A literature review. Turrialba 10:83-137.

Wringley G (1988) Coffee. Longman Scientific and Technical, John Wiley \& Sons, Inc., New York.

Vishveshwara S (1960) Occurrence of haploid in Coffea arabica L. cultivar kents. Indian Coffee 24:123-124. 